\title{
Primary School Teachers' Readiness Towards Heutagogy and Peeragogy
}

\author{
Choo Gui Chan ${ }^{1}$, Mohamed Amin Bin Embi ${ }^{1} \&$ Harwati Hashim ${ }^{1}$ \\ ${ }^{1}$ Faculty of Education, The National University of Malaysia \\ Correspondence: Universiti Kebangsaan Malaysia, 43600 Bangi, Selangor, Malaysia. Tel: 60-124-882-022.
}

Received: May 10, 2019

Accepted: June 10, 2019

Online Published: June 24, 2019

doi:10.20849/aes.v4i1.602

URL: https://doi.org/10.20849/aes.v4i1.602

\begin{abstract}
Over the decades, education is seen as a pedagogical relationship between the teacher and the learner. Traditionally, what a learner needed to learn, what knowledge and skills that should be taught were always decided by a teacher. However, education has transformed and moved from pedagogy to different approaches namely andragogy, heutagogy and peeragogy, the newest approach to education to suit the needs of the society. Therefore, the aim of this paper is to identify primary school teachers' acceptance of technology and to investigate their readiness towards Heutagogy and Peeragogy. This study also sought to identify possible demographic factors which may influence respondents' readiness towards Heutagogy and Peeragogy. Data were collected from 48 primary teachers in a primary school in Malaysia using a survey and were analysed using descriptive statistics. The results showed that the in-service teachers have a very positive readiness towards technology in Education as well as using heutagogy approach and peeragogy approach in their teaching. The study about the teachers' acceptance of technology, readiness towards Heutagogy and Peeragogy and the challenges faced are expected to provide useful information for the educators to provide support for future study.
\end{abstract}

Keywords: heautagogy, peeragogy, ICT, education

\section{Introduction}

Human's life has been transformed in one way or another due to globalization. The changes in the human's life have prompted some educators to argue that the traditional teaching methodology is no longer enough for the learners. Education has undergone several revolutions through research for the past thirty years to review how people learn and how teaching could and should be provided (Kenyon \& Hase, 2001). According to Jerald (2009), a broader set of "21st century skills" must be provided in school to the students in order to thrive in a rapidly evolving, technology-saturated world. Thus, changes are needed in education as it is argued that pedagogy in teacher education with little sense of the social, moral, and political aspects are not enough to prepare students to face challenges in the 21 st century.

It is undeniable that the pace of technological change is very rapid. Due to the rapid change of the society as well as the rapid growth of ICT, Ismail et al. (2013) stated that the technology brings a significant impact on educational development. Education has moved from pedagogy to different approaches namely andragogy, heutagogy and peeragogy, the newest approach to education to suit the needs of the society. Pedagogy is where the learners depend on the teachers, who is responsible for what is taught and how it is taught. Kenyon \& Hase (2001) said that andragogy provided many useful approaches for improving methodology; however, it still had connotations of a teacher-learner relationship. Heutagogy and peeragogy are extended approaches and have important implications for practice in the 21st century particularly in the development of individual capability. Heutagogy promotes learning as self-determined and non-linear, while peeragogy practises peer-to-peer and decentered learning. Both self-determined and peer-based learning are essential for performing tasks, problem solving and self-assessment which are important for 21 st century learning.

This study is assumed to be significant in several aspects. Firstly, this study provides some insights on the gender factor in association with teachers' perception towards incorporation of technology in education. Though technology is known as an important element in education nowadays, it does not mean that all of the teachers are ready for it as every teacher holds their own beliefs towards incorporation of technology in education. Therefore, this study would show is there any significant differences between male and female teachers concerning their perception on the roles of technology in assisting teaching and learning activities. It would help the stakeholders 
to understand the teachers better and they are able to visualize how their decisions on implementing of ICT are interpreted by the teachers.

This study will also create awareness and motivation among teachers to use heutagogy and peeragogy approaches incorporation of technology in classroom. For teachers who do not know what is heutagogy and peeragogy will be more likely to understand better how do they work so that the learners are able to maximise their learning process by learning independently, able to work in group and share their knowledge freely. Moreover, this study can create awareness among the primary teachers because teachers, especially primary teachers tend to neglect the use of ICT in teaching and learning. In short, Heutagogy and peeragogy approaches help to promote how to learn and how to work individually and together.

\section{Method}

A survey was done among 48 primary teachers from Petaling Jaya, Selangor. They were comprised of Malays, Chinese and Indian. However, they were not represented equally in number and there were also a mix number of male and female respondents. The participants' names and personal details are confidential. No names were mentioned in reporting the results of the study. The instrument used for carrying out this survey is in the form of questionnaire. There were 42 items all in total in the questionnaire. The questionnaire was divided into three sections, namely personal details, computer knowledge and Internet experience and UTAUT Model questions which including four main factors, namely performance expectancy (PE), effort expectancy (EE), social influence (SI), facilitating conditions (FC). These items covered were intended to elicit three major types of information from the subjects. They are:

(i) Questions aimed at eliciting personal data for classifying the sample into categories which provide basic for analytic, relational study.

(ii) Questions aimed mainly at eliciting information on in service teachers' computer knowledge and internet experience.

(iii) Questions aimed at eliciting information from the in service teachers in order to gain an insight regarding what factors that influence the acceptance of technology.

\section{Literature Review}

Education in Malaysia has undergone a several changes in order to increase the quality and effectiveness of learning process as well as to meet the aim of the national curriculum which is to create Malaysian students that are balanced, resilient, inquisitive, principled, informed, caring, patriotic, as well as an effective thinker, communicator, and team player (Malaysia Blueprint 2013-2025, pg. 105). Heutagogy and peeragogy are believed to be the newest approaches to uncover the most effective ways to do self-determined learning and collaborative learning, a new set of skills and competencies geared towards the 21 st century and beyond.

\subsection{ICT in Education}

Ismail et al. (2013) stated that the technology brings a significant impact on educational development. According to Chan (2002), the concept of ICT in education, as seen by the Ministry of Education, includes systems that enable information gathering, management, manipulation, access, and communication in various forms. The use of technology is viewed as a potentially powerful enabling tool, specifically for educational change and reform (Tinio, 2003). Many researchers reported their studies on the integration of technology in the process of teaching and learning as efforts to amplify students' performance, teaching effectiveness, as well as teachers' productivity (Ismail et al.,2013; Wang et al., 2008; Jamil and Shah, 2011). Many research studies have also revealed the benefits that can be achieved by students, teachers and administrators via integration of ICT in education (Jhurree, V., 2005). Malik and Shabbir (2008) and Saba (2009) emphasized on the effective usage of technology to produce new opportunities for self-directed learning as one of efforts to increase students' achievement. While Jhurree, V. (2005) stated that technology in education offers the following benefits to the educational community and the society:

(i) It is an enhanced learning environment for learners as it provides a motivating learning environment.

(ii) It is a powerful tool to supplement teachers' instruction in classroom.

(iii) It is an administrative tool for teachers and administrators.

(iv) It is a communication platform. Students, teachers, and administrators can communicate, exchange knowledge and concerns, meet experts and peers, and share work in collaborative projects through the use of technology. 
(v) It can prepare students to integrate the world of work and competition tomorrow.

\subsection{Heutagogy and Online Learning}

According to Hase and Kenyon (2001), heutagogy and it is an extension to andragogical approaches which provides the optimal approach to learning in the twenty-first century where the learners are served as "the major agent in their own learning, which occurs as a result of personal experiences". The learners get the full relinquishes ownership of the learning process, determine and decide what will be learned and how will be learned though the instructor would still facilitate the learning process by providing guidance and resource. Based on Hase, S., \& Kenyon, C. (2000), heutagogy is "the study of self-determined learning, may be viewed as a natural progression from earlier educational methodologies - in particular from capability development-and may well provide the optimal approach to learning in the twenty-first century". A key concept in heutagogy is that of double-loop learning and self-reflection (Argyris \& Schön, 1996, as cited in Hase \& Kenyon, 2000). Hase explained double-loop learning occurs when learners "question and test one's personal values and assumptions as being central to enhancing learning how to learn". In double-loop learning, learners consider the problem and the resulting action and outcomes, in addition to reflecting upon the problem-solving process and how it influences the learner's own beliefs and actions

In term of self-determined learning, the learner negotiates the learning process (Hase \& Kenyon, 2000). Web 2.0 design supports a heutagogical approach by allowing learners to direct and determine their learning path and by enabling them to take an active rather than passive role in their individual learning experiences. According to Blaschke (2012), heutagogical approach emphasises flexibility and the role of the teacher in providing resources. A teacher can provide the book, technological and different resources. However, the learner can become self-directed by choosing to do a project that will provide meaningful, purposeful and more life-oriented experience. A complete learning involves this reflection so that one may transfer knowledge from situation to situation knowledgeably and confidently and ensure capability.

\subsection{Peeragogy and Online Learning}

Based on Corneli and Danoff (2011), the theory of peeragogy, which is also known as paragogy is a new theory of peer-to-peer learning and teaching which "addresses the challenge of peer-producing a useful and supportive context for self-directed learning". Alexander et al. (2012) explained that peeragogy is about "peers learning together and helping each other learn". Each person is allowed to contribute to the group in their own way. On the other hand, according to Corneli et al. (2011), the theory of peeragogy (paragogy) was developed in the context of two online courses namely "DIY Math" and "Collaborative Lesson Planning". Peeragogy or paragogy is understood as a set of replicable techniques and patterns for effective peer learning and problem solving. Following are the five paragogical principles stated by Corneli et al.,

i. Context as a decentered center.

ii. Meta-learning as a font of knowledge.

iii. Peers are equal, but different.

iv. Learning is distributed and non-linear.

v. Realise the dream then wake up!

Peeragogy is an active learning with others. Corneli et al. explains that participants in a peeragogical endeavor collaboratively build emergent structures that are responsive to their changing context. Peeragogy offers a critical focus on peer learning as an extension of critical and constructivist approaches. Based on Rheingold (2014), best practices in classroom-based and online learning such as online open course emphasize learner autonomy and interactivity where knowledge is generated via peer-to-peer collaboration and crowdsourcing. Learners learn how to develop, implement, review and adjust their personal goals. Peer learning supports learner to develop knowledge and skills which enable them to;

i. Identify appropriate future options

ii. Review their strengths and for development

iii. Identify goals and plans for improvement

iv. Monitor their actions and review

v. Adjust plans as needed to achieve their goals. 


\section{Results}

Questionnaire had been distributed to 48 respondents to collect the data on SJKC Yuk Chyun's Primary School Teachers' Readiness towards Heutagogy and Peeragogy. The data gathered were analyzed in term of frequency counts and percentage distribution.

The findings were presented mainly in two parts, namely:

(i) The Demographic Data

(ii) Analysis of Data:

Research Question 1: What is the level of technology acceptance among SJKC Yuk Chyun's primary school teachers.

Research Question 2: What is the level of readiness for heutagogy among SJKC Yuk Chyun's primary school teachers.

Research Question 3: What is the level of readiness for peeragogy among SJKC Yuk Chyun's primary school teachers.

\subsection{Analysis and Interpretation of Data}

\subsubsection{The Demographic Data}

Table 1. Distribution of respondent according to gender, age, race and second method

\begin{tabular}{llll}
\hline Items & & Frequency & Percentage (\%) \\
\hline Gender & Male & 7 & 14.6 \\
\cline { 2 - 4 } & Female & 41 & 85.4 \\
\hline \multirow{2}{*}{ Age } & $20-29$ & 11 & 22.9 \\
\cline { 2 - 4 } & $30-39$ & 30 & 62.5 \\
\cline { 2 - 4 } & $40-49$ & 5 & 10.4 \\
\cline { 2 - 4 } & $50-59$ & 2 & 4.2 \\
\hline Quace & Malay & 11 & 23 \\
\cline { 2 - 4 } & Chinese & 36 & 75 \\
\cline { 2 - 4 } & Indian & 1 & 2 \\
\cline { 2 - 4 } & Diploma & 45 & 4.2 \\
\cline { 2 - 4 } & Bachelor's Degree & 2 & \\
\cline { 2 - 4 } & Post-graduate Degree & & 25 \\
\hline
\end{tabular}

The questionnaires are sent to 7 males in service teachers and 41 females in service teachers via email. The sample of study consists of $85.4 \%$ of female respondents and $14.6 \%$ of male respondents. All the respondents are coming from the different age category. The participants, totally 11 of them (22.9\%) are in the range of 20 -year-old to 24-year-old. Majority of 30 of the respondents, taking up $62.5 \%$ are in the range of 30 -year-old to 39 -year-old. There are 5 respondents with $10.4 \%$ who are in the range of 40 -year-old to 49 -year-old while there are only 2 respondents which is $4.2 \%$ are in the range of 50-year-old to 59-year-old.

The table also shows that the questionnaires are given to 11 Malay (23\%), 36 Chinese (75\%) and 1 Indian (2\%). Besides that, the number of in service teachers is fairly distributed with regards to their qualification. The sample of study consists of only 1 diploma holder (2\%). There are 45 in service teachers are bachelor degree holder $(93.75 \%)$ and 2 post-graduate degree holder $(4.2 \%)$.

4.1.2 Research Question 1: What Is the Level of Technology Acceptance Among SJKC Yuk Chyun's Primary School Teachers?

There are 4 items all together to answer the first research question. All results are expressed as percentages (\%). 
Table 2. Distribution of respondent according to their computer knowledge and Internet experience

\begin{tabular}{|c|c|c|c|}
\hline Items & & Frequency & Percentage (\%) \\
\hline \multirow{5}{*}{$\begin{array}{l}\text { How do you describe } \\
\text { your general computer } \\
\text { knowledge? }\end{array}$} & Very Poor & 0 & 0 \\
\hline & Poor & 0 & 0 \\
\hline & Moderate & 20 & 41.7 \\
\hline & Good & 24 & 50 \\
\hline & Very Good & 4 & 8.3 \\
\hline \multirow{5}{*}{$\begin{array}{l}\text { How would you describe } \\
\text { your Interne }\end{array}$} & Very Poor & 0 & 0 \\
\hline & Poor & 6 & 12.5 \\
\hline & Moderate & 19 & 39.6 \\
\hline & Good & 23 & 47.9 \\
\hline & Very Good & 0 & 0 \\
\hline \multirow{4}{*}{$\begin{array}{l}\text { How long have you been } \\
\text { using the Internet? }\end{array}$} & Don't use & 0 & 0 \\
\hline & $<1$ year & 0 & 0 \\
\hline & $1-3$ years & 0 & 0 \\
\hline & $>5$ years & 48 & 100 \\
\hline \multirow{4}{*}{$\begin{array}{l}\text { How often do you use the } \\
\text { Internet per day? }\end{array}$} & $<1$ hour & 0 & 0 \\
\hline & $1-3$ hours & 12 & 25 \\
\hline & $4-6$ hours & 21 & 43.75 \\
\hline & $>6$ hours & 15 & 31.25 \\
\hline
\end{tabular}

Generally, all of the respondents have basic general knowledge towards computer. There are $41.7 \%$ of respondents think that they have moderate level of general computer knowledge and 50\% of the respondents think they are good at it while $8.3 \%$ of them find themselves are very good at general computer knowledge. There are $41.7 \%$ of respondents think that they have moderate level of general computer knowledge. In term of Internet knowledge, there are $12.5 \%$ of the respondents who claim that they are poor at it. On the other hand, $39.6 \%$ of the respondents find themselves at the moderate level while there are $47.9 \%$ of the respondents think that they are good at it. The result shows that even though the respondents are confidence in computer knowledge, Internet knowledge might be a challenge for them.

In the 21 st century, technology and Internet indeed play an important role in our daily life. Therefore, we can see that all the respondents have been using Internet more than five years despite the age gap, race, and qualification. Though Internet is something we cannot avoid every day, it still depends on each individual how often they use the Internet each day. 12 respondents (25\%) spend 1 to 3 hours each day. Majority of the respondents, $43.75 \%$ spend 4 to 6 hours using Internet each day and 31.25\% of the respondents use Internet more than 6 hours a day.

4.1.3 Research Question 2: What Is the Level of Readiness for Heutagogy Among SJKC Yuk Chyun's Primary School Teachers? and Research Question 3: What Is the Level of Readiness for Peeragogy Among SJKC Yuk Chyun's Primary School Teachers?

Alshehri (2013) UTAUT Models questions have been edited and used to reflect second and third research questions. There are 42 items all together to elicit information from the in service teachers in order to gain an insight regarding what factors that influence the acceptance of technology and their readiness towards heutagogy and peeragogy. All results are expressed as percentages (\%).

Four main aspects have been categorised in the model questions, namely,

(i) performance expectancy (PE) (9 items)

(ii) effort expectancy (EE) (12 items)

(iii) social influence (SI) (12 items)

(iv) facilitating conditions (FC) (9 items) 


\subsubsection{Performance Expectancy (PE)}

Table 3. Aspect 1: Performance Expectancy (PE)

\begin{tabular}{|c|c|c|c|}
\hline \multirow[t]{2}{*}{ Items } & \multicolumn{3}{|c|}{ Percentage $(\%)$} \\
\hline & $\mathrm{SD}$ or $\mathrm{D}$ & $\mathrm{N}$ & A or SA \\
\hline 1. Using technology (ICT) in class enables to enhance my teaching in class. & 0 & 8.33 & 91.67 \\
\hline 2. Using technology (ICT) would save teachers' and learners' time. & 0 & 0 & 100 \\
\hline $\begin{array}{l}\text { 3. Using technology (ICT) would increase the quality of teaching and } \\
\text { learning process. }\end{array}$ & 0 & 16.67 & 83.33 \\
\hline $\begin{array}{l}\text { 4. Using heutagogy approach (self-directed learning) enables to enhance the } \\
\text { learners' learning process. }\end{array}$ & 0 & 33.33 & 66.67 \\
\hline $\begin{array}{l}\text { 5. Using heutagogy approach (self-directed learning) would save learners' } \\
\text { and teachers' time. }\end{array}$ & 0 & 25 & 75 \\
\hline $\begin{array}{l}\text { 6. Using heutagogy approach (self-directed learning) would increase the } \\
\text { quality of teaching and learning process. }\end{array}$ & 8.33 & 33.33 & 58.33 \\
\hline $\begin{array}{l}\text { 7. Using peeragogy approach (peer-to-peer learning) enables to enhance the } \\
\text { learners' learning process. }\end{array}$ & 8.33 & 8.33 & 75 \\
\hline $\begin{array}{l}\text { 8. Using peeragogy approach (peer-to-peer learning) would save learners' } \\
\text { and teachers' time. }\end{array}$ & 8.33 & 8.33 & 75 \\
\hline $\begin{array}{l}\text { 9. Using peeragogy approach (peer-to-peer learning) would increase the } \\
\text { quality of teaching and learning process. }\end{array}$ & 0 & 16.67 & 83.33 \\
\hline
\end{tabular}

Note: $\mathrm{SD}=$ Strongly Disagree; $\mathrm{D}=$ Disagree; $\mathrm{N}=$ Neutral; $\mathrm{A}=$ Agree; SA=Strongly Agree

Table 3 shows that positive responds are provided by the respondents towards performance expectancy. Majority and almost all the respondents strongly agreed that using technology (ICT) in class enables to enhance their teaching in class $(91.67 \%)$ and it would save teachers and learners' time (100\%). Though there are $66.67 \%$ and $75 \%$ of respondents find that heutagogy approach enables to enhance the learners' learning process and it save learners' and teachers' time; there are a small amount of respondents $(8.33 \%)$ doubt that heutagogy approach would increase the quality of teaching and learning process.

As to compared to heutagogy approach, the results show that the respondents are more confidence towards peeragogy as majority $75 \%$ of the respondents claim that peeragogy approach enables to enhance the learners' learning process and it can save their time. At the same time, a total of $83.33 \%$ of the respondents agreed and some of them strongly agreed that peeragogy approach would increase the quality of teaching and learning process.

\subsubsection{Effort Expectancy (EE)}

Table 4. Aspect 2: Effort Expectancy (EE)

\begin{tabular}{llll}
\hline Items & Percentage (\%) \\
\cline { 2 - 3 } & SD or D & N & SD or D \\
\hline 1. Learning to technology (ICT) in class is easy. & 0 & 16.67 & 83.33 \\
\hline $\begin{array}{l}\text { 2. Using technology (ICT) in Teaching and learning is easy. } \\
\text { 3. It is easy for me to become skillful at using technology (ICT) in my } \\
\text { teaching. }\end{array}$ & 0 & 8.33 & 91.67 \\
\hline $\begin{array}{l}\text { 4. By using technology (ICT) in teaching, I am able to teach easily in class. } \\
\text { 5. Learning to apply heutagogy approach (self-directed learning) in class is }\end{array}$ & 0 & 8.33 & 91.67 \\
easy. & 50 & 50 \\
\hline
\end{tabular}




\begin{tabular}{llccc}
\hline $\begin{array}{l}\text { 6. Using heautagogy approach (self-directed learning) in teaching and } \\
\text { learning is easy. }\end{array}$ & & 41.67 & 50 \\
\hline $\begin{array}{l}\text { 7. It is easy for learners to become skillful at using heutagogy approach } \\
\text { (self-directed learning) in my teaching. }\end{array}$ & & 54.55 & 45.45 \\
\hline $\begin{array}{l}\text { 8. By using heutagogy approach (self-directed learning) in teaching and } \\
\text { learning process, I am able to teach easily in class. }\end{array}$ & & 50 & 50 \\
\hline $\begin{array}{l}\text { 9. Learning to apply peeragogy approach (peer-to-peer learning) in class is } \\
\text { easy. }\end{array}$ & & 8.33 & 91.67 \\
\hline $\begin{array}{l}\text { 10. Using peeragogy approach (peer-to-peer learning) in teaching and } \\
\text { learning is easy. }\end{array}$ & & 8.33 & 91.67 \\
\hline $\begin{array}{l}\text { 11. It is easy for learners to become skilful at using peeragogy approach } \\
\text { (peer-to-peer learning) in my teaching }\end{array}$ & & 8.33 & 91.67 \\
\hline $\begin{array}{l}\text { 12. By using peeragogy approach (peer-to-peer learning) in teaching and } \\
\text { learning process, I am able to teach easily in class. }\end{array}$ & & & \\
\hline
\end{tabular}

Note: SD=Strongly Disagree; $\mathrm{D}=$ Disagree; N=Neutal; $\mathrm{A}=$ Agree; $\mathrm{SA}=$ Strongly Agree

One has to put on his effort in order to excel in technology. The positive thought would definitely make the learning journey easier. Table 3 shows the respondents have positive thoughts towards effort expectancy (EE). $83.33 \%$ of the respondent think that learning technology (ICT) in class is easy and most of them (91.67\%) think that using technology (ICT) in teaching and learning is easy. 100\% of the respondents think it is easy for them to become skilful at using technology (ICT) in their teaching. 91.67\% of the respondents agreed that by using technology (ICT) in teaching, they are able to teach easily in class. Although most of the teachers have positive attitude towards learning technology, only $50 \%$ of them agreed learning to apply heutagogy approach in class or in teaching and learning is easy. However, there are $8.33 \%$ of the in service teachers disagreed that using heutagogy approach in teaching and learning is easy. $54.55 \%$ of the teachers think it depends for learners to become skilful if heutagogy approach is used in the teaching while $45.45 \%$ of the learners think that the learners would be skilful by using heutagogy approach in teaching. Only $50 \%$ of the respondents agreed that they are able to teach easily in class by using heutagogy approach in teaching and learning process.

Majority (91.67\%) of the respondents agreed that learning to apply peeragogy approach in class or teaching and learning is easy. As to compare to heutagogy, $91.67 \%$ of the respondents thinks it is easier for learners to become skilful at using peeragogy approach in their teaching and by using peeragogy in teaching and learning process, they are able to teach easily in class.

\subsubsection{Social Influence (SI)}

Table 5. Aspect 3: Social Influence (SI)

\begin{tabular}{|c|c|c|c|}
\hline \multirow[t]{2}{*}{ Items } & \multicolumn{3}{|c|}{ Percentage (\%) } \\
\hline & SD or D & $\mathrm{N}$ & $\mathrm{SD}$ or $\mathrm{D}$ \\
\hline $\begin{array}{l}\text { 1. People who are important to me think that I should use ICT in my } \\
\text { teaching. }\end{array}$ & 0 & 25 & 75 \\
\hline 2. People who influence my behavior think that I should use ICT in teaching. & 0 & 25 & 75 \\
\hline 3. I would use ICT in my teaching if my friends and colleagues used them. & 0 & 8.33 & 91.67 \\
\hline 4. Minister of Education encourages teachers to use ICT in class. & 0 & 8.33 & 91.67 \\
\hline $\begin{array}{l}\text { 5. People who are important to me think that I should use heutagogy } \\
\text { approach (self-directed learning) in my teaching. }\end{array}$ & 0 & 41.67 & 58.33 \\
\hline $\begin{array}{l}\text { 6. People who influence my behavior think that I should use heutagogy } \\
\text { approach (self-directed learning) in teaching. }\end{array}$ & 0 & 41.67 & 58.33 \\
\hline $\begin{array}{l}\text { 7. I would use heutagogy approach (self-directed learning) in my teaching if } \\
\text { my friends and colleagues used them. }\end{array}$ & 0 & 41.67 & 58.33 \\
\hline
\end{tabular}




\begin{tabular}{llllc}
\hline $\begin{array}{l}\text { 8. Minister of Education encourages teachers to use heutagogy approach } \\
\text { (self-directed learning) in class. }\end{array}$ & 0 & 25 & 75 \\
\hline $\begin{array}{l}\text { 9. People who are important to me think that I should use peeragogy } \\
\text { approach (peer-to-peer learning) in my teaching. }\end{array}$ & & 25 & 75 \\
\hline $\begin{array}{l}\text { 10. People who influence my behavior think that I should use peeragogy } \\
\text { approach (peer-to-peer learning) in teaching. }\end{array}$ & & 25 & 75 \\
\hline $\begin{array}{l}\text { 11. I would use peeragogy approach (peer-to-peer learning) in my teaching if } \\
\text { my friends and colleagues used them. }\end{array}$ & 0 & 16.77 & 83.33 \\
\hline $\begin{array}{l}\text { 12. Minister of Education encourages teachers to use peeragogy approach } \\
\text { (peer-to-peer learning) in class. }\end{array}$ & & 16.77 & 83.33 \\
\hline
\end{tabular}

Note: $\mathrm{SD}=$ Strongly Disagree; $\mathrm{D}=$ Disagree; N=Neutral; A=Agree; SA=Strongly Agree

Social influence would be one of the important aspect that affect one's thought and beliefs. $75 \%$ of the respondents agreed that people who are important to them and people who influence their behaviour think that they should use ICT in their teaching. 83.33\% of the teachers claimed that they would use ICT in their teaching if their friends and colleagues used them. The result shows that social influence plays an important role in moulding one's behaviour. Again, the willingness of using heutagogy approach in class is high because $75 \%$ of the teachers agreed that minister of education encourages teachers to use heutagogy approach in class.

In term of peeragogy, $75 \%$ of the respondents agreed that people who are important to them and people who always influence their behaviour think that they should use peeragogy approach in their teaching. $83.33 \%$ of the respondents said that they would use peeragogy approach in their teaching if their friends and colleagues used them. The same amount of the respondents does not deny that the Minister of Education encourages teachers to use peeragogy approach in class.

\subsubsection{Facilitating Conditions (FC)}

Table 6. Aspect 4: Facilitating Conditions (FC)

\begin{tabular}{|c|c|c|c|}
\hline \multirow[t]{2}{*}{ Items } & \multicolumn{3}{|c|}{ Percentage $(\%)$} \\
\hline & SD or D & $\mathrm{N}$ & SD or D \\
\hline 1. I have the resources necessity to integrate ICT in class. & 0 & 8.33 & 91.67 \\
\hline 2. I have the knowledge necessity to integrate ICT in my teaching. & 0 & 8.33 & 91.67 \\
\hline $\begin{array}{l}\text { 3. There is a specific person or group available for assistance with any } \\
\text { technical problem I may encounter. }\end{array}$ & 16.33 & 8.33 & 75.34 \\
\hline $\begin{array}{l}\text { 4. I have the resources necessity to integrate heutagogy approach } \\
\text { (self-directed learning) in class. }\end{array}$ & 8.33 & 25 & 66.67 \\
\hline $\begin{array}{l}\text { 5. I have the knowledge necessity to integrate heutagogy approach } \\
\text { (self-directed learning) in my teaching. }\end{array}$ & 8.33 & 25 & 66.67 \\
\hline $\begin{array}{l}\text { 6. There is a specific person or group available for assistance with any } \\
\text { problem I may encounter regarding heutagogy approach. }\end{array}$ & 8.33 & 25 & 66.67 \\
\hline $\begin{array}{l}\text { 7. I have the resources necessity to integrate peeragogy approach } \\
\text { (peer-to-peer learning) in class. }\end{array}$ & 0 & 18.18 & 81.82 \\
\hline $\begin{array}{l}\text { 8. I have the knowledge necessity to integrate peeragogy approach } \\
\text { (peer-to-peer learning) in my teaching. }\end{array}$ & 0 & 25 & 75 \\
\hline $\begin{array}{l}\text { 9. There is a specific person or group available for assistance with any } \\
\text { problem I may encounter regarding peeragogy approach. }\end{array}$ & 0 & 36.36 & 63.64 \\
\hline
\end{tabular}

Note: $\mathrm{SD}=$ Strongly Disagree; $\mathrm{D}=$ Disagree; $\mathrm{N}=$ Neutral; $\mathrm{A}=$ =Agree; $\mathrm{SA}=$ Strongly Agree

Facilitating conditions might be one of the aspects that helps or hinders teachers from using technology in their 
teaching. A positive result, $91.67 \%$ of the respondents agreed that they have the resources as well as the knowledge necessity to integrate ICT in class or teaching. $75.43 \%$ of the teachers agreed that there is a specific person or group available for assistance with any technical problem they may encounter while $16.33 \%$ of the respondents disagreed with the statement.

Only $66.67 \%$ of the respondents agreed that they have the resourced and the knowledge necessity to integrate heutagogy approach in class or in their teaching. There are a small group of the respondents $(8.33 \%)$ disagreed that they have enough resources and knowledge necessity to integrate heutagogy approach in their teaching. The same amount of $66.67 \%$ of respondents claimed that there is a specific person or group available for assistance with any technical problem they may encounter.

The table shows that the respondents are more confidence towards peeragogy approach. $81.82 \%$ of the respondents agreed that they have the resources necessity to integrate peeragogy approach in class. However, only $75 \%$ of the respondents claimed that they have the knowedge necessity to integrate peeragogy approach in their teaching. Only $63.64 \%$ of the respondents agreed with the statement that there is a specifid person or group available for assistance with any problem they may encounter regarding peeragogy approach.

\section{Discussion}

It is clear from this survey research that SJKC Yuk Chyun's in service teachers have very positive attitudes towards technology in Education as well as using heutagogy approach and peeragogy approach in teaching and learning process. The in service teachers show that they have certain amount of general knowledge of computer and the Internet. Most of them place positive feedback regarding implication of heutagogy and peeragogy approach in teaching as they agree that these approach would not only save the time of the teachers but it also save the time of the learners. They also agree that by using two approaches in class would increase the quality of learning. However, there is a small amount of students seem to be uncertain about the situation as they have nobody to refer to when they face any problems regarding the two approaches.

The study also shows that despite the age gap or the qualification of the teachers, the factors do not hinder any of the in service teachers to use technology in class. The teachers seemed to realise the importance of using technology in class as it plays an important role in 21 st century teaching. Not only using the technology, teachers are aware that using the correct approaches in class would help the learners to learn. Although heutagogy approach and peeragogy approach are not too common to the teachers and learners in Malaysia, it is glad to see the teachers have positive attitudes towards the approaches and believe that the approaches would help the learners to learn better in and out of the classroom.

\subsection{The Level of Technology Acceptance Among SJKC Yuk Chyun's Primary School Teachers}

- The teachers are all well-prepared for the rapid change of the technology. At least 50\% of the respondents claimed that they have good general knowledge regarding the computer and Internet skill. This is important as they need the basic knowledge in order to use ICT in class.

- All of the teachers have at least more than 5 years' experience in using Internet. Therefore, it can see that all of the teachers despite how all they are, they are willing to enhance themselves and adapt to the changes of the society needs. At the same time, they are able to deliver the latest learning strategies to the learners so that they have help to improve the learning quality of the learners.

\subsection{The Level of Readiness for Heutagogy And Peeragogy Among SJKC Yuk Chyun's Primary School Teachers}

\section{(i) Aspect 1: Performance Expectancy (PE)}

- Performance Expectancy (PE) is understand as "the degree to which the user expects that using the system will help or her to attain gains in job performance" (Venkatesh et al., 2003, p.447). Teachers need to possess a good and positive mind set in order to improve their job performance.

- The teachers are accepting heutagogy and peeragogy approaches as they believe that using technology (ICT) in class not only enables them to enhance their teaching in class but it can also enhance the learning process of the learners.

- Though the teachers believe that both heutagogy and peeragogy approaches can improve the quality of teaching and learning process, it is obvious that the teachers are more confidence towards peeragogy approach as to compared to the heutagogy approach. It is because primary school pupils might have difficulty to guide and direct themselves in learning. 


\section{(ii) Apsect 2: Effort Expectancy (EE)}

- Effort expectancy, similar with performance expectancy, can be defined as "the degree of ease associated with the use of the system" (Venkatesh et al., 2003, p.450). It is understandable that it is not easy to start using a new system. One needs to put on extra miles to understand a particular system before applying and implementing it into the education system.

- Majority of the teachers in SJKC Yuk Chyun have the positive attitudes towards the new system. Although most of the teachers have positive attitude towards learning technology, some of the teachers doubted that using heutagogy approach in class or in teaching is easy.

- As to compared to heutagogy approach, the teachers believe that apply peeragogy approach in class or teaching and learning is easy. They also think that they can teach easily in class by using peeragogy approach in their teaching.

\section{(iii) Aspect 3: Social Influence (SI)}

- Social influence is always considering as an important factor that will affect one's behaviour. Social influence is defined as "the degree to which an individual perceives that important others believe he or she should use the new system" (Venkatesh et al., 2003, p.451). The decision and choice that made by the teachers can be seen that they are influenced by the people they think who are important to them for example their colleagues, their superior, their students as well as their family members. They claimed that if their colleagues use the new approaches in class, they would also use the approaches in their teaching as they believe what they do is beneficial to the learners.

- Ministry of Education is also the major key at influencing the attitude and belief of the teachers. The teachers tend to adopt and adapt the new approaches in order to improve their job performance as well as to meet the expectation of their superior and the Minister of Education. Associate with 21st century teaching and learning, teachers believe that the Minister of Education would encourage the use of heutagogy and peeragogy in teaching.

(iv) Aspect 4: Facilitating Conditions (FC)

- Facilities, resources and materials are the important elements in order to make a system effective. The use of technology seems to be common to everyone but unfortunately, not all the families or schools have the equal facilities. The teachers in SJKC Yuk Chyun have the positive attitude as they acknowledged that the facilitating conditions in school and at home are equally good.

- The teachers are encouraged to use the approaches because they have the basic resources necessity to integrate ICT in class. Therefore, the teachers believe that it would not be too difficult to integrate heutagogy and peeagogy approaches in their teaching. They

- The teachers believe that with the knowledge that they have, they are able to convey self-directed learning and peer-to-peer learning strategies to the leaners. At the same time, the teachers believe that they can easily get help if they face problems regarding heutagogy and peeragogy approaches.

\section{Conclusion}

In a nutshell, the result from the study shows that different aspects do play an important role at affecting the teachers' attitude and behaviour. The positive result shows that the teachers have positive intention to use the new approaches in their teaching. In short, the teachers are willing to adapt and adopt to the changes that caused by the rapid change of the technology (ICT). The willingness of using or trying new system or approaches in class can caused by different aspects. The teachers need to understand each aspect that help or hinder them from trying heutagogy and peeragogy approaches in their teaching. Not everyone would hold a positive belief or attitude towards the new approaches. Therefore, teachers need to put more effort to understand the use of each approach and investigate the effectiveness of each approach. Prior belief of a system can hinder one from exploring new approaches. Therefore, teachers need to take into account whether the surroundings or behaviours of people around them that might influence their beliefs towards heutagogy and peeragogy approaches.

Ministry of Education plays an important role in promoting heutagogy and peeragogy approaches. First of all, the Ministry of Education should impart positive beliefs so that they can increase the confidence level of the teachers. Besides, best practices should be shared more often to the teachers around the nation. It might help the teachers to have better understand towards the approaches and able to use those approaches in their teaching effectively. If the teachers have incorrect or negative belief towards the new approaches, it might negatively affect their attitude towards applying heutagogy and peeragogy approaches in class. At the same time, the learners would not benefit from it as well. 
Last but not least, this study shows that the teachers on the whole show very positive attitudes and they are to understand and to explore heutagogy and peeragogy approaches in their teaching. In order to promote heutagogy and peeragogy approaches in class, the authority should provide sufficient facilities, materials, resources and help to the teachers nationwide. This would help to create interest and awareness among the teachers. On top of that, teachers know who should they refer to if they have any problems regarding the approaches. The authority should be more supportive so that the teachers would not be discouraged if they face any difficulties and challenges when dealing with heutagogy and peeragogy approaches in their teaching.

\section{References}

Alexander, B., Allison, P., Barondeau, R., Breitbart, D., Burroughs, S., Corneli, J., \& Walker, G. (2012, August). The Peeragogy Handbook (Version 0.98). All content here is Public Domain (CC0). Retrieved from http://metameso.org/peeragogy-2.01-ebook.pdf

Argyris, C., \& Schon, D. A. (1996). Organiational learning II. Addison Wesley.

Blaschke, L. M. (2012). Heutagogy and lifelong learning: A review of heutagogical practice and self-determined learning. The International Review of Research in Open and Distributed Learning, 13(1), 56-71.

Chan, F. M. (2002, October). ICT in Malaysian schools: Policy and strategies. In A Workshop on the Promotion of ICT in Education to Narrow the Digital Divide (pp. 15-22).

Corneli, J., \& Danoff, C. J. (2011). Paragogy: Synergizing individual and organizational learning, p.33. Published on Wikiversity. Cit.

Hase, S., \& Kenyon, C. (2000). From andragogy to heutagogy. Ulti-BASE In-Site.

Ismail, I., Bokhare, S., Azizan, S., \& Azman, N. (2013). Teaching via mobile phone: A case study on Malaysian teachers' technology acceptance and readiness. Journal of Educators Online, 10(1), 1-38.

Jamil, M., \& Shah, J. H. (2011). Technology: its potential effects on teaching in higher education. New Horizons in Education, 59(1), 38-51.

Jerald, C. D. (2009). Defining a 21 st century education, p. 16. Center for Public education.

Jhurree, V. (2005). Technology integration in education in developing countries: Guidelines to policy makers. International Education Journal, 6(4), 467-483.

Kenyon, C., \& Hase, S. (2001). Moving from Andragogy to Heutagogy in Vocational Education.

Malik, S., \& Shabbir, M. S. (2008). Perceptions of university students on self-directed learning through learning technology. European Journal of Scientific Research, 24(4), 567-574.

Rheingold, H. (Ed.). (2014). The peeragogy handbook. Jointly published by Pierce Press and Pub Dom Ed.

Saba, A. (2009). Benefits of technology integration in education.

Tinio, V. L. (2003). ICT in education. Bangkok: UNDP-Asia Pacific Development Information Programme (APDIP).

Venkatesh, V., Morris, M. G., Davis, G. B., \& Davis, F. D. (2003). User acceptance of information technology: Toward a unified view. MIS Quarterly, 27(3), 425-478.

\section{Copyrights}

Copyright for this article is retained by the author(s), with first publication rights granted to the journal.

This is an open-access article distributed under the terms and conditions of the Creative Commons Attribution license (http://creativecommons.org/licenses/by/4.0/). 